\title{
Zingiberaceae extracts for pain: a systematic review and meta-analysis
}

\author{
Shaheen E. Lakhan ${ }^{1 *}$, Christopher T. Ford ${ }^{1,2}$ and Deborah Tepper $^{3}$
}

\begin{abstract}
Background: Members of the family Zingiberaceae including turmeric, ginger, Javanese ginger, and galangal have been used for centuries in traditional medicine. Preclinical studies of Zingiberaceae extracts have shown analgesic properties. This study aims to systematically review and meta-analyze whether extracts from Zingiberaceae are clinically effective hypoalgesic agents.

Methods: Literature was screened from electronic databases using the key words Zingiberaceae AND pain OR visual analogue score (VAS) to identify randomized trials. From this search, 18 studies were identified, and of these, 8 randomized, double-blinded, placebo-controlled trials were found that measured pain by VAS for inclusion in the meta-analysis.

Results: Findings indicated significant efficacy of Zingiberaceae extracts in reducing subjective chronic pain (SMD - 0.67; $95 \% \mathrm{Cl}-1.13$ to $-0.21 ; P=0.004)$. A linear dose-effect relationship was apparent between studies $\left(R^{2}=0.71\right)$. All studies included in the systematic review reported a good safety profile for extracts, without the renal risks associated with non-steroidal anti-inflammatory drugs, and with similar effectiveness.

Conclusion: Our findings indicated that Zingiberaceae extracts are clinically effective hypoalgesic agents and the available data show a better safety profile than non-steroidal anti-inflammatory drugs. However, both non-steroidal anti-inflammatory drugs and Zingiberaceae have been associated with a heightened bleeding risk, and there have been no comparator trials of this risk. Further clinical studies are recommended to identify the most effective type of Zingiberaceae extract and rigorously compare safety, including bleeding risk.
\end{abstract}

Keywords: VAS, Ginger, Turmeric, Galangal, Curcumin, Curcuma

\section{Background}

Turmeric (Curcuma longa), ginger (Zingiber officinale), Javanese ginger (Curcuma zanthorrhiza), and galangal (Alpinia galanga), which are members of the family Zingiberaceae, have been used for centuries in traditional medicine [1, 2]. Zingiberaceae have received scientific interest as dietary anti-inflammatory agents $[3,4]$, and pilot human trials have indicated benefits for chronic diseases including osteoarthritis, rheumatoid arthritis, and major depressive disorder [5-7]. Commonly prescribed medications for pain, principally non-steroidal anti-inflammatory drugs (NSAIDs), have side effects with long-term use [8], leading to calls for safer tools for the management of chronic pain [9].

\footnotetext{
* Correspondence: slakhan@gnif.org

'Global Neuroscience Initiative Foundation, Los Angeles, California, USA

Full list of author information is available at the end of the article
}

Turmeric's principal bioactive is the polyphenol curcumin [10], which can be extracted using organic solvents [11]. Curcumin has anti-inflammatory properties [12]; its mechanisms include down-regulation of nuclear factor (NF)-кB [13] and cyclooxygenase 2 (Cox-2) [14]. Animal studies have shown antinociceptive effects of oral curcumin [15] and indicated the involvement of ATP-sensitive potassium channels [16]. Pilot human studies of curcumin have shown promise for improving symptoms of rheumatoid arthritis and inflammatory bowel disease [5, 17]. Curcumin is poorly bioavailable and it is likely that its benefits are mediated via secondary metabolites [18].

The primary anti-inflammatory components of ginger are gingerol and zingerone [3, 19]; however, other ginger components also have anti-inflammatory activities in vivo [20]. Mechanisms of action include modulation of leukotriene and prostaglandin synthesis, and inhibition 
of NF-kB $[3,19,21]$. One meta-analysis was previously conducted on ginger for pain, but the authors concluded too few rigorous studies were available at that time to make a confident recommendation [22].

Galangal polyphenols were shown to protect against lipopolysaccharide-induced injury in a rodent model, indicating a functional anti-inflammatory effect in vivo $[23,24]$. In vitro work has suggested that the galangal component 1 '-acetoxychavicol modulates a transient receptor potential (TRP) cation channel [25]. Javanese ginger contains curcumin [26] and zanthorrhizol, which is also a Cox-2 inhibitor [27]. Javanese ginger extract and zanthorrhizol have anti-inflammatory effects in vivo [28] and Javanese ginger extract displayed anti-nociceptive effects in mice [29].

Preclinical studies of Zingiberaceae extracts have shown antinociceptive effects [29-32]. Previous reviews have considered Zingiberaceae species for particular clinical situations [33, 34], but no prior reviews have examined all Zingiberaceae for chronic pain. The present review and meta-analysis aims to include randomized controlled trials (RCTs) that have used Zingiberaceae extracts for a condition involving chronic pain. Since the time window for absorption and action of Zingiberaceae extracts is unknown, but is probably less than $24 \mathrm{~h}$ based on data for other herbal extracts [35], we only included studies involving treatment periods lasting $24 \mathrm{~h}$ or longer. While chronic pain is typically defined as pain present for at least 3 months, for this meta-analysis we included pain present for greater than $24 \mathrm{~h}$ to capture a sufficient number of studies of non-acute pain.

The aim of this systematic review and meta-analysis is to assess the potential for hypoalgesic effects of Zingiberaceae extracts in conditions involving chronic pain.

\section{Methods}

\section{Literature search strategy}

The meta-analysis was conducted according to Cochrane and PRISMA guidelines [36]. Published studies were identified by searching PubMed, ScienceDirect, and Cochrane Library databases, using the following search terms, which include the common and taxonomic names of the Zingiberaceae species, and specific bioactive components found in each plant: turmeric, curcumin, ginger, galangal, Zingiberaceae, Curcuma, Zingiber, Kaempferia, Alpinia, curcuminoid, turmerone, gingerol, shogaol, zingiberene, zingiberol, zingerone, curcumene, galangin, zanthorrhizol, AND pain OR visual analogue score OR VAS. The references within each identified report were manually reviewed. Publications were included that were published before December 2014.

Selection of studies for inclusion in the systematic review Studies were included in the systematic review if they met the following criteria: a) the study was randomized; b) the study included a patient group with chronic pain, i.e., pain lasting $24 \mathrm{~h}$ or longer; c) extracts from one or more Zingiberaceae species were given either alone or in combination with agents intended to increase the bioavailability of the Zingiberaceae bioactives, but not together with other treatments or non-Zingiberaceae herbal extracts; d) Zingiberaceae extracts were given for $24 \mathrm{~h}$ or longer, and e) pain was measured as a study outcome. Papers were excluded before review stage if they were not peer-reviewed, full-length, original research reports (for example they were reviews, editorials, conference abstracts, etc.)

\section{Selection of studies for inclusion in the meta-analysis}

Further selection criteria were applied for inclusion of papers into the meta-analysis. Papers were excluded from the meta-analysis that were: a) not placebocontrolled; b) not double-blinded; or c) did not measure pain using VAS.

\section{Data extraction}

Group sample sizes, and means and standard deviations for pain, were extracted from each included report for pooled analysis. To focus the meta-analysis and maximize the accuracy of comparisons between studies, we chose to only extract and analyze data for the VAS measurement of pain. Other measurements varied widely between the included papers, which investigated divergent patient groups. Where studies involved more than one treatment group, data was only extracted for the group treated with the Zingiberaceae extract in its least processed and/or highest dose form. For studies reporting results for multiple time points, data were extracted for the longest treatment time period, except in the study by Black et al. [37], where, because pain in the placebo group decreased over time after the eccentric exercise protocol, the earliest time point of $24 \mathrm{~h}$ supplementation was selected.

\section{Data analysis}

The standardized mean difference (SMD) was calculated allowing for a continuous pain rating scale such as the VAS. The SMD is a useful statistical tool when studies all assess the same outcome but measure it in a variety of ways. Effect sizes for all included studies were calculated and weighted by variance. In accordance with Higgins et al., 2003 [38], heterogeneity was considered to be low at $\mathrm{I}^{2} \leq 25 \%$, moderate at $\mathrm{I}^{2} \leq 50 \%$, high at $\mathrm{I}^{2} \leq 75 \%$, and very high at $\mathrm{I}^{2}>75 \%$. All calculations were performed using the StatsDirect software package, version 2.7.9. P-values were considered significant at $\leq 0.05$. The potential for publication bias was assessed using the funnel plot method [39]. A symmetric funnel plot indicates that there was little bias based on the sample size of the analyzed 
studies, whereas an asymmetric funnel plot suggests that a meta-analysis may be flawed because of inappropriate weight given to small versus large studies. We have no specific reason to suspect bias in this research area. Since the included studies for quantitative analysis used a wide range of Zingiberaceae extract doses, a post-hoc decision was made to draw a dose-effect curve for SMDs against $\mathrm{mg}$ of extract/day used in each study.

\section{Results}

We screened 43 unique records and rejected 25 of these because either they were not controlled or they investigated pain lasting for less than $24 \mathrm{~h}$. The systematic review included 18 randomized trials for qualitative analysis and the meta-analysis included 8 RCTs (Fig. 1). Those 10 RCTs that were included in the qualitative synthesis, but not the quantitative analysis, were excluded from the meta-analysis either because they were not double-blinded, or they were not placebo-controlled, or they measured pain by a method other than VAS.

\section{Systematic review}

Chronic pain has traditionally been described as pain present for 12 weeks or longer, although this definition has been shifting to include a less rigid time frame. Chronic pain as defined by the International Association for the Study of Pain (IASP) as "pain that persists beyond normal tissue healing time". This meta-analysis utilized a broad definition of chronic pain to include pain

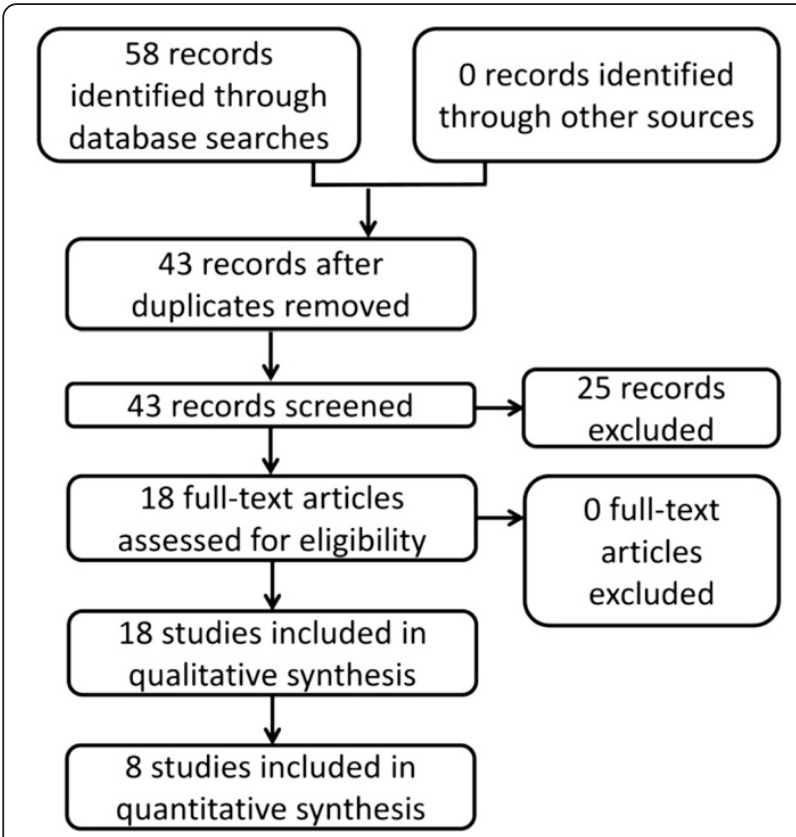

Fig. 1 PRISMA flow chart showing the numbers of identified, screened, included, and excluded studies for the systematic review (qualitative synthesis) and meta-analysis (quantitative analysis) greater than $24 \mathrm{~h}$ in order to capture a meaningful number of studies.

Chronic pain is a symptom of many long-term medical conditions, including cancer, arthritis, nerve damage after traumatic injury, and neuropathy associated with chronic conditions such as diabetes. It has serious adverse effects on multiple dimensions of quality of life [40]. In Europe, $19 \%$ of adults were found to experience chronic pain of moderate to severe intensity in a survey published in 2006, and of the survey respondents, $40 \%$ felt that management of their pain was inadequate [41]. Side effects of currently prescribed treatments for chronic pain have led to calls for the development of new and safer approaches [8]. This systematic review explores randomized human trials of Zingiberaceae extracts for chronic pain, defined for this meta-analysis as pain lasting for longer than $24 \mathrm{~h}$.

\section{Chronic pain in arthritic conditions}

The first randomized trial of Zingiberaceae extracts that measured pain as an outcome investigated the effects of $510 \mathrm{mg}$ of ginger extract/day for osteoarthritis using a crossover, double-blinded, placebo-controlled study design. The ginger-treated group reported significantly less pain compared with the placebo group for the first period before crossover, but not after crossover, while the ibuprofen group showed a stronger reduction in pain [42]. Shortly thereafter, another double-blinded, randomized, placebo-controlled trial was conducted for osteoarthritis, again with a treatment dose of $510 \mathrm{mg} /$ day, but using a mixed Zingiberaceae treatment comprising ginger and galangal extracts. A moderate reduction of pain on walking was detected after 6 weeks of treatment, compared with the placebo group [43]. A 6-month, placebo-controlled study in symptomatic gonarthritis (knee arthritis) patients investigated the effects of a higher dose of $1000 \mathrm{mg} /$ day of ginger extract with crossover between ginger and placebo groups at 3 months. In the second period after crossover, significantly less pain was reported in the ginger group, compared with the placebo group [44]. Ginger extract was used in a further study for osteoarthritis at $340 \mathrm{mg} /$ day dosage, and was found to be equally as effective as diclofenac for pain relief, but with a superior safety profile, indicated by significantly fewer adverse gastropathic changes in the ginger group, compared with the diclofenac group [45]. A trial of curcumin for knee osteoarthritis, in which patients took $1000 \mathrm{mg}$ curcumin/day as an adjuvant to diclofenac treatment, found no significant difference between the curcumin + diclofenac group and the placebo + diclofenac group [46]. An open-label comparative trial treated patients with knee osteoarthritis using diclofenac + placebo, ginger extract (1500 mg/day) + placebo, or diclofenac + ginger. The results showed that all three 
treatment groups reported significantly less pain after 12 weeks of treatment than at baseline, and the diclofenac plus ginger group reported significantly less pain than the diclofenac + placebo and ginger + placebo treatment groups [47]. Another trial in knee osteoarthritis, investigating the effects of supplementation with $1000 \mathrm{mg} /$ day of turmeric extract, found significantly less pain in the treatment group compared with the placebo group [48]. A trial comparing $1500 \mathrm{mg} /$ day of turmeric extract with ibuprofen for knee osteoarthritis concluded that turmeric extract and ibuprofen were equally effective in reducing pain [49]. In a different study, treatment with $1500 \mathrm{mg} /$ day of curcuminoids was found to significantly reduce pain in knee osteoarthritis compared with a placebo group [50]. In summary, there have been multiple randomized trials of Zingiberaceae extracts for arthritis (osteoarthritis and gonarthritis), which have mostly found moderate reductions in reported subjective pain, with Zingiberaceae extracts showing comparable effectiveness to standard NSAID treatments. The evidence for turmeric extracts/curcumin for chronic pain in osteoarthritis is stronger than that for ginger extracts.

\section{Pain in primary dysmenorrhea}

A trial of ginger extract for primary dysmenorrhea found that $1000 \mathrm{mg}$ of ginger extract/day resulted in a reduction of pain with equal effectiveness to each of two NSAID control groups (mefenamic acid and ibuprofen) [51]. A placebo-controlled trial was conducted, with patients taking $1500 \mathrm{mg}$ of ginger extract/day. Significant reductions in the severity and duration of pain were detected in the ginger-treated group, compared with the placebo group [52]. Although only two randomized studies were available, their findings suggest that ginger extract may be an effective treatment for pain in primary dysmenorrhea.

\section{Pain in delayed onset muscle soreness}

Volunteers who performed a strenuous eccentric exercise protocol (18 eccentric extensions of the elbow flexor muscles against resistance at $120 \%$ of their concentric one-repetition maximum) and were treated with either raw or heat-treated ginger extracts at $2000 \mathrm{mg} /$ day dosage reported less pain associated with delayed onset muscle soreness than a placebo group [36]. A similar study was performed using a high-bioavailability curcumin formulation, with $400 \mathrm{mg} /$ day curcumin given to volunteers who underwent a milder eccentric exercise protocol (downhill running on a treadmill for $45 \mathrm{~min}$ ). This study also found a reduction in pain for the treated group, compared with the placebo group, however this difference was significant only for the muscles of the anterior thigh [53]. These studies suggest that Zingiberaceae extracts may have a moderate hypoalgesic effect for delayed onset muscle soreness following eccentric exercise. Further trials are recommended to determine the most effective extract type and dose.

\section{Pain in recovery from surgery}

A double-blinded, placebo controlled trial of high-dose curcumin $(2000 \mathrm{mg} /$ day $)$ for patients recovering from laparoscopic cholecystectomy found a significant reduction in pain at weeks 1 and 3 of treatment in the treated group, compared with the placebo group [54]. The results of this single study suggest curcumin may alleviate pain following surgery.

\section{Chronic pain in irritable bowel syndrome}

A pilot study of turmeric extract for irritable bowel syndrome (IBS), which had two dose groups, both with relatively low intake (72 and $144 \mathrm{mg} /$ day, respectively), found a modest but significant reduction in abdominal pain for both the lower- and higher-dose turmeric extract treatment groups [55]. Another trial investigated Javanese ginger extract for IBS, with patients taking $60 \mathrm{mg}$ of extract/day for 18 weeks in a double-blinded, placebo-controlled study. In this trial, no significant difference in pain was found between the treatment and placebo groups [56]. In light of findings for Zingiberaceae extracts for other conditions, we recommend further trials in IBS using higher treatment doses.

\section{Pain in cancer radiotherapy-induced dermatitis}

A double-blinded, placebo controlled trial of breast cancer patients undergoing radiotherapy investigated the effects of very high-dose curcumin $(6000 \mathrm{mg} /$ day $)$ on pain associated with radiation dermatitis. Although significant improvement was seen for some other radiation dermatitis symptoms with curcumin treatment, no significant difference was seen for pain scores between the curcumin-treated and placebo groups [57]. Based on this single study, curcumin cannot be recommended as a pain management tool for radiation dermatitis.

\section{Meta-analysis}

The studies that were determined to be eligible for inclusion in the quantitative analysis included five studies using ginger extracts, two studies using curcuminoids or curcumin, and one study using Javanese ginger extract. The patient groups included four groups with arthritis (osteoarthritis or gonarthritis), one group with IBS, one group with primary dysmenorrhea, one group recovering from surgery, and one group with muscle soreness following eccentric exercise. All studies included adult participants at least 18 years of age. Table 1 lists the methods and results of each included study, organized by date of publication. In all included studies, the majority of subjects were female, and in one study, all of the 
Table 1 Characteristics of included studies for meta-analysis

\begin{tabular}{|c|c|c|c|c|c|c|c|c|c|c|}
\hline \multirow[t]{2}{*}{ Study } & \multirow[t]{2}{*}{ Patient group } & \multicolumn{2}{|c|}{$\begin{array}{l}\text { Number of } \\
\text { subjects }\end{array}$} & \multicolumn{2}{|c|}{ Percent female } & \multicolumn{2}{|c|}{ Mean age $\pm S D$ (years) } & \multirow[t]{2}{*}{ Intervention } & \multirow[t]{2}{*}{ Control } & \multirow[t]{2}{*}{ Results for pain } \\
\hline & & Treated & Control & Treated & Control & Treated & Control & & & \\
\hline $\begin{array}{l}\text { Bliddal et al., } \\
2000 \text { [42] }\end{array}$ & $\begin{array}{l}\text { Osteoarthritis of } \\
\text { knee or hip. }\end{array}$ & 56 & 56 & 73 & 73 & $\begin{array}{l}\text { Age range } \\
24-87\end{array}$ & $\begin{array}{l}\text { Age range } \\
24-87\end{array}$ & $\begin{array}{l}\text { Capsules containing } 170 \mathrm{mg} \\
\text { ginger extract, } 3 \text { capsules per } \\
\text { day for } 3 \text { weeks. }\end{array}$ & $\begin{array}{l}\text { Placebo (crossover } \\
\text { design). }\end{array}$ & $\begin{array}{l}\text { Pain was not significantly different } \\
\text { between the ginger and placebo } \\
\text { groups. }\end{array}$ \\
\hline $\begin{array}{l}\text { Altman et al. } \\
2001[43]\end{array}$ & $\begin{array}{l}\text { Osteoarthritis of } \\
\text { knee. }\end{array}$ & 124 & 123 & 60 & 63 & $64.0 \pm 11.5$ & $66.3 \pm 11.6$ & $\begin{array}{l}\text { Capsules containing } 255 \mathrm{mg} \text { of } \\
\text { mixed ginger and galangal } \\
\text { rhizome extracts, } 2 \text { capsules per } \\
\text { day for } 6 \text { weeks. }\end{array}$ & $\begin{array}{l}\text { Placebo (parallel } \\
\text { design). }\end{array}$ & $\begin{array}{l}\text { Pain on walking was significantly } \\
\text { lower in the ginger/galangal group } \\
\text { after } 6 \text { weeks of treatment compared } \\
\text { with the placebo group. }\end{array}$ \\
\hline $\begin{array}{l}\text { Wigler et al., } \\
2003[44]\end{array}$ & $\begin{array}{l}\text { Symptomatic } \\
\text { gonarthritis. }\end{array}$ & 29 & 29 & 79 & 79 & $\begin{array}{l}\text { Age range } \\
42-85\end{array}$ & $\begin{array}{l}\text { Age range } \\
42-85\end{array}$ & $\begin{array}{l}\text { Capsules containing } 250 \mathrm{mg} \\
\text { ginger rhizome extract, } 4 \\
\text { capsules per day for } 3 \text { months. }\end{array}$ & $\begin{array}{l}\text { Placebo (crossover } \\
\text { design). }\end{array}$ & $\begin{array}{l}\text { Pain was significantly lower in the } \\
\text { ginger group compared with the } \\
\text { placebo group. }\end{array}$ \\
\hline $\begin{array}{l}\text { Brinkhaus et al., } \\
2005[56]\end{array}$ & $\begin{array}{l}\text { Irritable bowel } \\
\text { syndrome. }\end{array}$ & 24 & 58 & 58 & 62 & $49.5 \pm 14.5$ & $49.0 \pm 9.1$ & $\begin{array}{l}\text { Capsules containing } 20 \mathrm{mg} \\
\text { Javanese ginger extract, } 3 \\
\text { capsules per day for } 18 \text { weeks. }\end{array}$ & $\begin{array}{l}\text { Placebo (parallel } \\
\text { design). }\end{array}$ & $\begin{array}{l}\text { Pain was not significantly different } \\
\text { between the Javanese ginger and } \\
\text { placebo groups. }\end{array}$ \\
\hline $\begin{array}{l}\text { Black et al., } \\
2010[37]\end{array}$ & $\begin{array}{l}\text { Muscle soreness } \\
\text { following exercise. }\end{array}$ & 20 & 20 & 65 & 65 & $20.6 \pm 0.6$ & $21.4 \pm 0.8$ & $\begin{array}{l}\text { Capsules containing } 333 \mathrm{mg} \\
\text { ginger rhizome extract, } 6 \\
\text { capsules per day for } 3 \text { days } \\
\text { following eccentric exercise. }\end{array}$ & $\begin{array}{l}\text { Placebo (parallel } \\
\text { design). }\end{array}$ & $\begin{array}{l}\text { Pain was significantly lower in the } \\
\text { ginger group compared with the } \\
\text { placebo group. }\end{array}$ \\
\hline $\begin{array}{l}\text { Agarwal et al., } \\
2011 \text { [54] }\end{array}$ & $\begin{array}{l}\text { Recovering from } \\
\text { surgery. }\end{array}$ & 25 & 25 & 84 & 80 & $38.4 \pm 12.8$ & $37.2 \pm 12.7$ & $\begin{array}{l}\text { Capsules containing } 500 \mathrm{mg} \\
\text { curcumin, } 4 \text { capsules per day for } \\
3 \text { weeks. }\end{array}$ & $\begin{array}{l}\text { Placebo (parallel } \\
\text { design). }\end{array}$ & $\begin{array}{l}\text { Pain was significantly lower in the } \\
\text { curcumin group compared with the } \\
\text { placebo group. }\end{array}$ \\
\hline $\begin{array}{l}\text { Rahnama et al., } \\
2012 \text { [52] }\end{array}$ & $\begin{array}{l}\text { Primary } \\
\text { dysmenorrhea. }\end{array}$ & 59 & 46 & 100 & 100 & $21.4 \pm 2.0$ & $21.3 \pm 2.2$ & $\begin{array}{l}\text { Capsules containing } 500 \mathrm{mg} \\
\text { ginger rhizome powder, } 3 \\
\text { capsules per day for } 5 \text { days. }\end{array}$ & $\begin{array}{l}\text { Placebo (parallel } \\
\text { design). }\end{array}$ & $\begin{array}{l}\text { Pain was significantly lower in the } \\
\text { ginger group compared with the } \\
\text { placebo group. }\end{array}$ \\
\hline $\begin{array}{l}\text { Panahi et al., } \\
2014 \text { [50] }\end{array}$ & $\begin{array}{l}\text { Osteoarthritis of } \\
\text { the knee. }\end{array}$ & 19 & 21 & 73 & 81 & $57.32 \pm 8.78$ & $57.57 \pm 9.05$ & $\begin{array}{l}\text { Capsules containing } 500 \mathrm{mg} \\
\text { curcuminoids and } 5 \mathrm{mg} \text { black } \\
\text { pepper extract (bioavailability } \\
\text { enhancer), } 3 \text { capsules per day } \\
\text { for } 6 \text { weeks. }\end{array}$ & $\begin{array}{l}\text { Placebo (parallel } \\
\text { design). }\end{array}$ & $\begin{array}{l}\text { Pain was significantly more reduced } \\
\text { in the curcuminoid treatment group, } \\
\text { compared with the placebo group. }\end{array}$ \\
\hline
\end{tabular}


subjects were female. While this could be interpreted to imply bias in sampling or selection, it can also be interpreted as being due to the known higher risk of females for arthritis [58], IBS [59], and gallstones necessitating laparoscopic cholecystectomy [60].

\section{Publication bias}

Following the methods of Egger et al., 1997 [39], a funnel plot was drawn for standard error against effect size (Fig. 2) to assess the possibility of publication bias, for example, the selective reporting of trials showing positive results, but not those producing negative results in the literature. The funnel plot was not fully symmetrical, which is an indicator for possible bias, but bias could not be concluded due to lack of statistical significance (Egger's test, $P=0.10$; a P-value less than 0.05 would demonstrate significant bias). In addition, inconsistency between studies was very high $\left(\mathrm{I}^{2}=87.5 \%\right)$, a factor that can contribute to asymmetry in funnel plots without necessarily implying bias.

\section{Meta-analysis of Zingiberaceae extracts for pain}

One of the inclusion criteria by which the 8 RCTs of Zingiberaceae extracts included in the meta-analysis were selected was that they all used the same measurement tool (VAS) for the assessment of pain. A randomeffects meta-analysis was performed according to the methods of DerSimonian and Laird, 1986 [61] (Fig. 3). This was necessary because of the heterogeneity of effects in the included studies. This analysis decreased the heterogeneity and allows for meaningful therapeutic findings. The standardized mean difference (SMD) for pain was large $(-0.67,95 \% \mathrm{CI}:-1.13$ to -0.21$)$, with significantly lower reported subjective pain in the experimental group compared with the control group $(P=0.004)$. Heterogeneity between studies was very high $\left(\mathrm{I}^{2}=87.5 \%\right)$. SMDs and confidence intervals for studies included in the meta-analysis are shown in Table 2.

\section{Dose-dependent effect of Zingiberaceae extracts for pain}

To determine whether the reduction in subjective pain by turmeric showed a dose-effect relationship across the 7 studies included in the quantitative meta-analysis, a scatter plot was drawn between the SMD for each study and the total dose of Zingiberaceae extract taken by subjects per day (Fig. 4). The results suggested a linear dose-effect relationship $\left(R^{2}=0.71\right)$.

\section{Discussion}

Compared with placebo controls, an overall moderate to large effect of Zingiberaceae extracts (including turmeric, ginger, and Javanese ginger) was found for reported chronic pain. While there was substantial heterogeneity between studies in their effect sizes, this may partly be explained by the wide variability in the doses of Zingiberaceae extracts used in each study. A doseresponse curve was plotted and revealed a strong doseeffect relationship.

No previous meta-analyses have considered all Zingiberaceae for chronic pain, but one prior analysis was conducted on ginger extracts only. The conclusion of that study was that there were insufficient studies on ginger at that time to make any recommendation on the effectiveness of ginger extracts for pain [22]. Metaanalyses have been conducted on Zingiberaceae extracts for several other parameters. A meta-analysis of curcumin

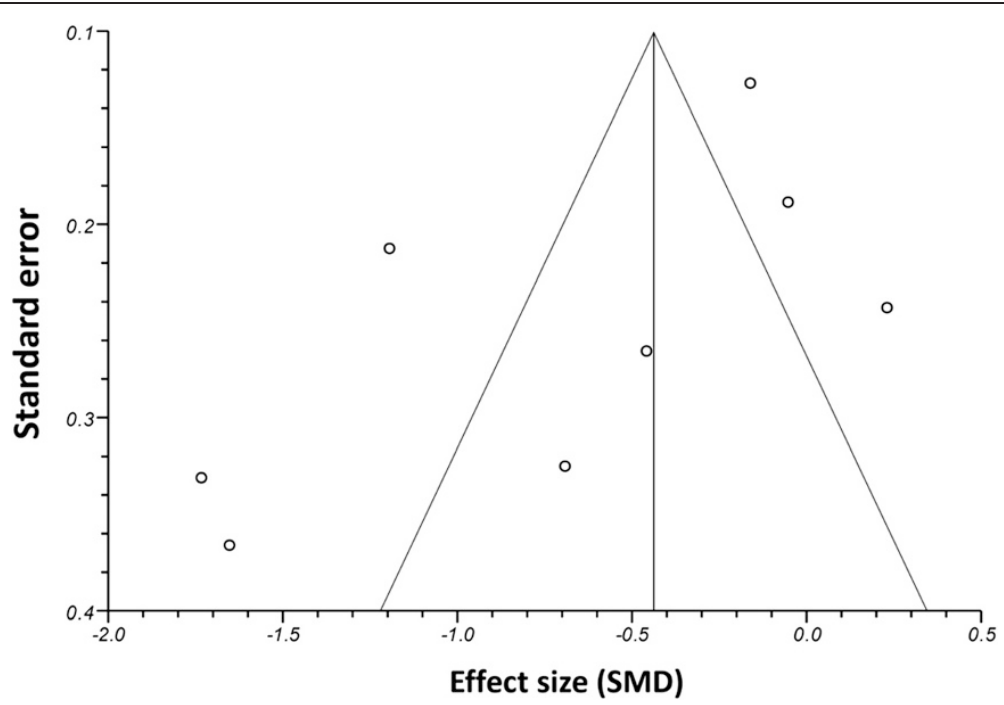

Fig. 2 A funnel plot for pain, showing standard error plotted against effect size (SMD). Each data point represents one RCT included in the meta-analysis. The plot was not completely symmetrical, indicating potential bias, but bias could not be concluded due to a lack of statistical significance (Egger's test, $P=0.10)$. A high degree of inconsistency between studies $\left(I^{2}=87.5\right)$ may contribute to the asymmetry of the funnel plot 


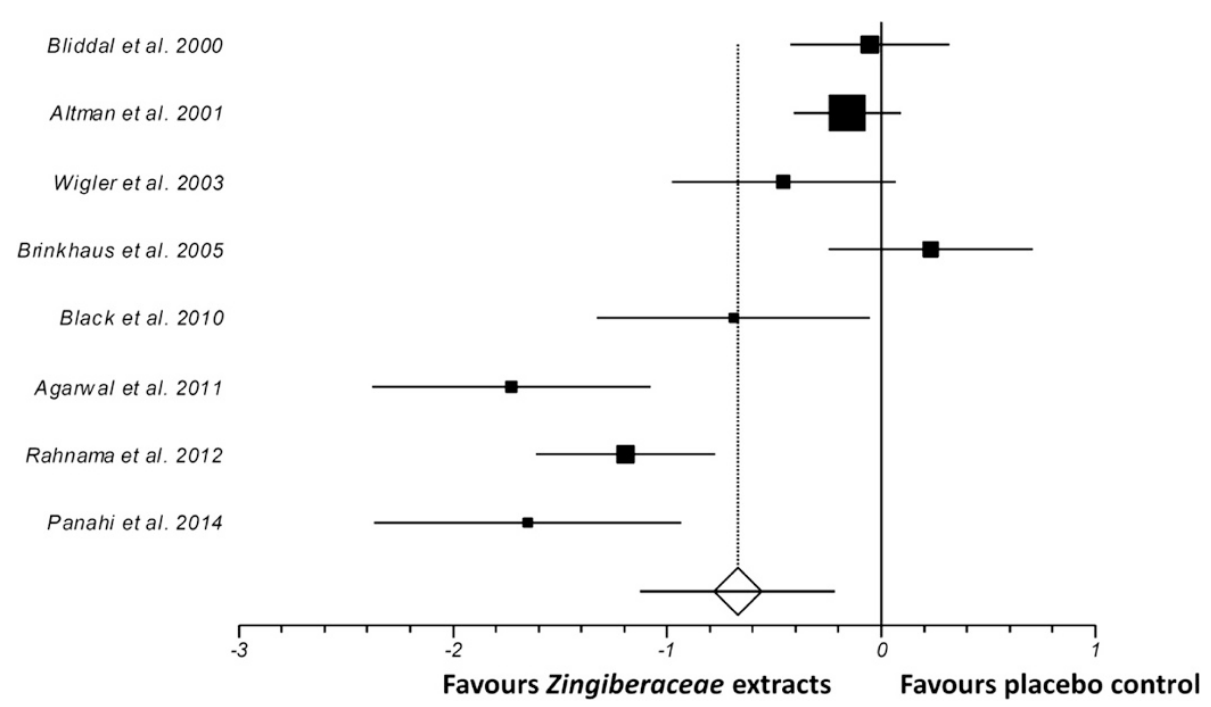

Fig. 3 Random-effects meta-analysis Forest plot showing standardized mean differences (SMDs) for each study of Zingiberaceae extracts included in the quantitative analysis, sorted by date of publication. The meta-analysis findings indicated that Zingiberaceae extracts significantly reduced subjective pain ( $P=0.004 ; S M D-0.67 ; 95 \% \mathrm{Cl}-1.13$ to -0.21 ). Earlier studies tended to use lower doses, which may explain the tendency for more recent studies to have larger effect sizes. Each study is represented by a square, with the area of the square corresponding to the weight given to that study in the meta analysis (weighting based on the number of subjects in each trial). The estimated overall effect size is displayed as a diamond. Horizontal lines show $95 \%$ confidence intervals

for blood lipid levels did not find any significant effects [62]. A meta-analysis of ginger extracts for chemotherapyinduced nausea and vomiting did not identify any significant benefit compared with placebo [63], but two other meta-analyses of ginger for the treatment of nausea and vomiting induced by pregnancy [64] and during postoperative recovery [65], respectively, found significant

Table 2 Effect sizes (SMDs) and confidence intervals for each study included in the meta-analysis. Negative SMDs show a reduction of pain in the treatment group for that study compared with the placebo control group

\begin{tabular}{llllll}
\hline Study & $N$ (treatment) & N (control) & SMD & $\begin{array}{l}95 \% \\
\text { Cl low }\end{array}$ & $\begin{array}{l}95 \% \\
\text { Cl high }\end{array}$ \\
\hline $\begin{array}{l}\text { Bliddal et al. } \\
\text { 2000 [42] }\end{array}$ & 56 & 56 & -0.05 & -0.42 & -0.32 \\
$\begin{array}{l}\text { Altman et al. } \\
\mathbf{2 0 0 1} \text { [43] }\end{array}$ & 124 & 123 & -0.16 & -0.41 & 0.09 \\
$\begin{array}{l}\text { Wigler et al. } \\
\mathbf{2 0 0 3} \text { [44] }\end{array}$ & 29 & 29 & -0.46 & -0.98 & 0.07 \\
$\begin{array}{l}\text { Brinkhaus et al. } \\
\mathbf{2 0 0 5} \text { [56] }\end{array}$ & 24 & 58 & 0.23 & -0.24 & 0.71 \\
$\begin{array}{l}\text { Black et al. } \\
\mathbf{2 0 1 0} \text { [37] }\end{array}$ & 20 & 20 & -0.69 & -1.33 & -0.05 \\
$\begin{array}{l}\text { Agarwal et al. } \\
\mathbf{2 0 1 1} \text { [54] }\end{array}$ & 25 & & & & \\
$\begin{array}{l}\text { Rahnama et al. } \\
\mathbf{2 0 1 2} \text { [52] }\end{array}$ & 25 & -1.73 & -2.38 & -1.08 \\
$\begin{array}{l}\text { Panahi et al. } \\
\mathbf{2 0 1 4} \text { [50] }\end{array}$ & 19 & 46 & -1.19 & -1.61 & -0.77 \\
\hline
\end{tabular}

improvement of symptoms by ginger extract treatment compared with placebo controls.

Our results indicate that Zingiberaceae extracts may be a useful tool for clinical pain management. However, certain side effects have been reported that may limit the use of Zingiberaceae extracts for specific patient groups. Allergic reaction to Zingiberaceae extracts occurs rarely [66]. Rodent studies have indicated the potential for Zingiberaceae extracts to cause hepatotoxicity [67], and so their use is cautioned in patients with

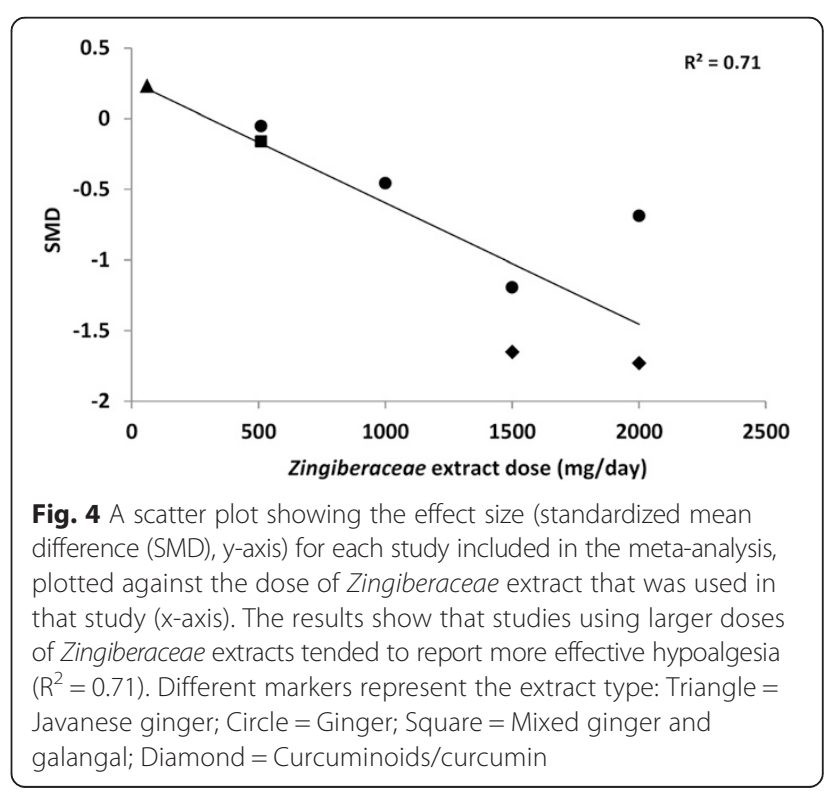


existing liver dysfunction. In addition, Zingiberaceae extracts have been reported to have anticoagulant activities [68] and may potentially exacerbate clotting disorders [69]. Nausea (usually mild) is a reported potential effect of Zingiberaceae extracts; however, Drozdov et al., 2012 [46] reported a superior gastropathic safety profile for ginger extract compared with diclofenac treatment in osteoarthritis patients. The study included in our systematic review that used the highest dose, with patients taking $6000 \mathrm{mg} /$ day of curcumin for 4-7 weeks, reported no significant adverse events and no significant increase in gastropathy (diarrhea) in the curcumin group compared with the placebo group [57].

\section{Study limitations}

This meta-analysis has several limitations. One is the inclusion of only a small number of studies (8 RCTs); although those studies that were included met very rigorous criteria, all of the included studies were randomized, double-blinded, placebo-controlled, and each used the same measurement tool (VAS) to quantify subjective pain. Another limitation is that the included studies showed very high heterogeneity. This variability is, however, likely to be at least partly due to the strong dose-effect relationship that we identified and the wide range of doses used among the studies under analysis (60-2000 $\mathrm{mg}$ of extract/day). The study of different Zingiberaceae species and patient populations in each trial may also contribute to the heterogeneity. The number of included studies was too small to perform subgroup analysis. A final limitation is that the included studies showed a strong gender skew towards female subjects. Further study in male populations would help to confirm whether Zingiberaceae extracts offer uniform pain relief across genders, although there is no clear biological reason to suspect any difference between genders in the response to Zingiberaceae extracts.

Although the studies included in the meta-analysis did not report significant adverse events from Zingiberaceae treatment, there are indications that caution needs to be exercised in recommending treatment without further studies. Zingiberaceae extracts are generally regarded as safe in lower dosages of concentrated extracts $[18,69]$. At higher dosages, there may be an increased risk of bleeding secondary to impairment of the clotting cascade or platelet dysfunction $[68,70]$, although this risk is not well defined. Turmeric supplementation has been associated with oxalate kidney stones [71]. A toxicology analysis of curcumin and its derivatives showed there can be a hepatotoxic effect that is dose-related [72]. Ginger and turmeric have an antiplatelet effect, and coupling either of them with NSAIDs can increase the risk of significant bleeding [73]. The degree to which these supplements may increase bleeding risk is not well known, however it is recommended that they be stopped two weeks prior to any surgery or significant dental procedure [74].

\section{Conclusions}

Chronic pain is a symptom of numerous medical disorders that may severely reduce quality of life, and its management is a core requirement of clinical care. Drugs commonly used for the relief of chronic pain have side effects that may interdict their use. Our results show that Zingiberaceae rhizome extracts, which have a good record of safety in human studies, offer effective relief from chronic pain. The dose-dependent effect identified implies that higher doses may potentially increase the effect further. The caveat to these findings is that they are based on a relatively small number of RCTs (8 studies), though these studies were included according to rigorous criteria. Long term and larger safety studies of these supplements, particularly at higher doses, are suggested. In summary, the available evidence suggests that Zingiberaceae extracts have hypoalgesic effects for chronic pain. We recommend further study of high-dose Zingiberaceae extracts for chronic pain management in clinical practice, and we also encourage focused assessment to determine the most effective Zingiberaceae species, extract doses, and bioactive chemicals; such research may potentially facilitate the development of higher potency hypoalgesic agents based on Zingiberaceae bioactives.

\section{Competing interests}

The authors declare that they have no competing interests.

\section{Authors' contributions}

Conceived and designed the experiments: SEL, CTF. Performed the experiments: SEL, CTF. Analyzed the data: SEL, CTF. All authors participated in the preparation of the manuscript, and read and approved the final manuscript.

\section{Author details}

${ }^{1}$ Global Neuroscience Initiative Foundation, Los Angeles, California, USA. ${ }^{2}$ Department of Musculoskeletal Biology, Institute of Ageing and Chronic Disease, The University of Liverpool, Liverpool, UK. ${ }^{3}$ Neurological Institute, Cleveland Clinic, Cleveland, Ohio, USA.

Received: 21 March 2015 Accepted: 6 May 2015

Published online: 14 May 2015

\section{References}

1. Gupta SC, Sung B, Kim JH, Prasad S, Li S, Aggarwal BB. Multitargeting by turmeric, the golden spice: From kitchen to clinic. Mol Nutr Food Res. 2013:57:1510-28

2. Prasad S, Aggarwal B. Turmeric, the golden spice: From traditional medicine to modern medicine. In: Benzie I, Wachtel-Galor S, editors. Herbal Medicine. 2nd ed. Boca Raton: FL, USA, CRC Press; 2011.

3. Lantz RC, Chen GJ, Sarihan M, Solyom AM, Jolad SD, Timmermann BN. The effect of extracts from ginger rhizome on inflammatory mediator production. Phytomedicine. 2007;14:123-8.

4. Prasad S, Gupta SC, Tyagi AK, Aggarwal BB. Curcumin, a component of golden spice: From bedside to bench and back. Biotech Advances. 2014;32(6):1053-64. doi:10.1016/j.biotechadv.2014.04.004. 
5. Chandran B, Goel A. A randomized, pilot study to assess the efficacy and safety of curcumin in patients with active rheumatoid arthritis. Phytother Res. 2012;26:1719-25.

6. Leach MJ, Kumar S. The clinical effectiveness of ginger (Zingiber officinale) in adults with osteoarthritis. Int J Evid Based Healthc. 2008;6:311-20.

7. Lopresti AL, Maes M, Maker GL, Hood SD, Drummond PD. Curcumin for the treatment of major depression: A randomised, double-blind, placebo controlled study. J Affect Disord. 2014;167:368-75.

8. McDowell K, Clements JN. How can NSAIDs harm cardiovascular and renal function? JAAPA. 2014;27:12-5.

9. McCarberg B, Gibofsky A. Need to develop new nonsteroidal anti-inflammatory drug formulations. Clin Ther. 2012;34:1954-63.

10. Tayyem RF, Heath DD, Al-Delaimy WK, Rock CL. Curcumin content of turmeric and curry powders. Nutr Cancer. 2006;55:126-31.

11. Verghese J, Joy MT. Isolation of the colouring matter from dried turmeric (Curcuma longa L.) with ethyl acetate. Flav Fragr J. 1989;4:31-2.

12. Asher GN, Spelman K. Clinical utility of curcumin extract. Alt Ther Health Med. 2013;19:20-2.

13. Sandur SK, Pandey MK, Sung B, Ahn KS, Murakami A, Sethi G, et al. Curcumin, demethoxycurcumin, bisdemethoxycurcumin, tetrahydrocurcumin and turmerones differentially regulate anti-inflammatory and anti-proliferative responses through a ROS-independent mechanism. Carcinogenesis. 2007;28:1765-73.

14. Samad T, Abdi S. Cyclooxygenase-2 and antagonists in pain management. Curr Op Anaesthesiol. 2001;14:527-32

15. Tajik H, Tamaddonfard E, Hamzeh-Gooshchi N. The effect of curcumin (active substance of turmeric) on the acetic acid-induced visceral nociception in rats. Pak J Biol Sci. 2008;11:312-4

16. De Paz-Campos MA, Chavez-Pina AE, Ortiz MI, Castaneda-Hernandez G. Evidence for the participation of ATP-sensitive potassium channels in the antinociceptive effect of curcumin. Korean J Pain. 2012;25:221-7.

17. Holt PR, Katz S, Kirshoff R. Curcumin therapy in inflammatory bowel disease: a pilot study. Digest Dis Sci. 2005;50:2191-3.

18. Gupta SC, Kismali G, Aggarwal BB. Curcumin, a component of turmeric: from farm to pharmacy. Biofactors. 2013;39:2-13.

19. Hsiang CY, Lo HY, Huang HC, Li CC, Wu SL, Ho TY. Ginger extract and zingerone ameliorated trinitrobenzene sulphonic acid-induced colitis in mice via modulation of nuclear factor-kB activity and interleukin-1 $\beta$ signalling pathway. Food Chem. 2013;136:170-7.

20. Funk JL, Frye JB, Oyarzo JN, Timmermann BN. Comparative effects of two gingerol-containing Zingiber officinale extracts on experimental rheumatoid arthritis. J Nat Prod. 2009;72:403-7.

21. Thomson M, Al-Qattan KK, Al-Sawan SM, Alnaqeeb MA, Khan I, Ali M. The use of ginger (Zingiber officinale Rosc.) as a potential anti-inflammatory and antithrombotic agent. Prostaglandins Leukot Essent Fatty Acids. 2002;67:475-8

22. Terry R, Posadzki P, Watson LK, Ernst E. The use of ginger (Zingiber officinale) for the treatment of pain: a systematic review of clinical trials. Pain Med. 2011;12:1808-18

23. Cao R, Fu K, Lv X, Li W, Zhang N. Protective effects of kaempferol on lipopolysaccharide-induced mastitis in mice. Inflammation. 2014;37(5):1453-8. doi:10.1007/s10753-014-9870-9.

24. Shu YS, Tao W, Miao QB, Lu SC, Zhu YB. Galangin dampens mice lipopolysaccharide-induced acute lung injury. Inflammation. 2014;37(5):1661-8. doi:10.1007/s10753-014-9894-1.

25. Narukawa M, Koizumi K, Iwasaki Y, Kubota K, Watanabe T. Galangal pungent component, 1'-acetoxychavicol acetate, activates TRPA1. Biosci Biotech Biochem. 2010;74:1694-6.

26. Nihayati E, Wardiyati T, Retnowati R, Soemarno $S$. The curcumin content of temulawak (Curcuma xanthorriza Roxb.) rhizome as affected by N, K, and micronutrients B, Fe, Zn. Agrivita. 2013;35:218-26.

27. Lee SK, Hong CH, Huh SK, Kim SS, Oh OJ, Min HY, et al. Suppressive effect of natural sesquiterpenoids on inducible cyclooxygenase (COX-2) and nitric oxide synthase (iNOS) activity in mouse macrophage cells. J Env Pathol Toxicology Oncol. 2002;21:141-8.

28. Kim MB, Kim C, Song Y, Hwang JK. Antihyperglycemic and anti-inflammatory effects of standardized Curcuma xanthorrhiza Roxb. extract and its active compound xanthorrhizol in high-fat diet-induced obese mice. Evid Based Comp Alt Med. 2014; 205915

29. Devaraj S, Esfahani AS, Ismail S, Ramanathan S, Yam MF. Evaluation of the antinociceptive activity and acute oral toxicity of standardized ethanolic extract of the rhizome of Curcuma xanthorrhiza Roxb. Molecules. 2010;15:2925-34

30. Banafshe HR, Hamidi GA, Noureddini M, Mirhashemi SM, Mokhtari R, Shoferpour M. Effect of curcumin on diabetic peripheral neuropathic pain: possible involvement of opioid system. Eur J Pharmacol. 2014;723:202-6.

31. Zhao X, Xu Y, Zhao Q, Chen CR, Liu AM, Huang ZL. Curcumin exerts antinociceptive effects in a mouse model of neuropathic pain: descending monoamine system and opioid receptors are differentially involved. Neuropharmacology. 2012;62:843-54.

32. Zhu Q, Sun Y, Yun X, Ou Y, Zhang W, Li JX. Antinociceptive effects of curcumin in a rat model of postoperative pain. Sci Rep. 2014;4:4932.

33. Al-Nahain A, Jahan R, Rahmatullah M. Zingiber officinale: A potential plant against rheumatoid arthritis. Arthritis. 2014;2014:1-8. doi:10.1155/2014/ 159089.

34. Cheppudira B, Fowler M, McGhee L, Greer A, Mares A, Petz L, et al. Curcumin: a novel therapeutic for burn pain and wound healing. Exp Opin Invest Drugs. 2013;22:1295-303.

35. Del Rio D, Rodriguez-Mateos A, Spencer JP, Tognolini M, Borges G, Crozier A. Dietary (poly)phenolics in human health: structures, bioavailability, and evidence of protective effects against chronic diseases. Antiox Redox Signal. 2013;18:1818-92

36. Liberati A, Altman DG, Tetzlaff J, Mulrow C, Gøtzsche PC, loannidis JP, et al. The PRISMA statement for reporting systematic reviews and meta-analyses of studies that evaluate health care interventions: explanation and elaboration. PLoS Med. 2009;6:e1000100.

37. Black CD, Herring MP, Hurley DJ, O'Connor PJ. Ginger (Zingiber officinale) reduces muscle pain caused by eccentric exercise. J Pain. 2010;11:894-903.

38. Higgins JP, Thompson SG, Deeks JJ, Altman DG. Measuring inconsistency in meta-analyses. BMJ. 2003;327:557-60.

39. Egger M, Smith GD, Schneider M, Minder C. Bias in meta-analysis detected by a simple, graphical test. BMJ. 1997;315:629-34.

40. Becker N, Bondegaard TA, Olsen AK, Sjøgren P, Bech P, Eriksen J. Pain epidemiology and health related quality of life in chronic non-malignant pain patients referred to a Danish multidisciplinary pain center. Pain. 1997;73:393-400

41. Breivik H, Collett B, Ventafridda V, Cohen R, Gallacher D. Survey of chronic pain in Europe: Prevalence, impact on daily life, and treatment. Eur J Pain. 2006;10:287-7.

42. Bliddal H, Rosetzsky A, Schlichting P, Weidner MS, Andersen LA, Ibfelt HH, et al. A randomized, placebo-controlled, cross-over study of ginger extracts and ibuprofen in osteoarthritis. Osteoarthr Cartilage. 2000;8:9-12

43. Altman RD, Marcussen KC. Effects of a ginger extract on knee pain in patients with osteoarthritis. Arthritis Rheum. 2001;44:2531-8.

44. Wigler I, Grotto I, Caspi D, Yaron M. The effects of Zintona EC (a ginger extract) on symptomatic gonarthritis. Osteoarthr Cartil. 2003;11:783-9.

45. Drozdov VN, Kim VA, Tkachenko EV, Varvanina GG. Influence of a specific ginger combination on gastropathy conditions in patients with osteoarthritis of the knee or hip. J Alt Comp Med. 2012;18:583-8.

46. Pinsornsak P, Niempoog S. The efficacy of Curcuma longa L. extract as an adjuvant therapy in primary knee osteoarthritis: a randomized control trial. J Med Assoc Thai. 2012:95:S51-8.

47. Paramdeep G. Efficacy and tolerability of ginger (Zingiber officinale) in patients of osteoarthritis of knee. Indian J Physiol Pharmacol. 2013:57:177-83.

48. Madhu K, Chanda K, Saji MJ. Safety and efficacy of Curcuma longa extract in the treatment of painful knee osteoarthritis: a randomized placebo-controlled trial. Inflammopharmacology. 2013;21:129-36.

49. Kuptniratsaikul V, Dajpratham P, Taechaarpornkul W, Buntragulpoontawee M, Lukkanapichonchut P, Chootip C, et al. Efficacy and safety of Curcuma domestica extracts compared with ibuprofen in patients with knee osteoarthritis: a multicenter study. Clin Interv Aging. 2014;9:451-8.

50. Panahi Y, Rahimnia AR, Sharafi M, Alishiri G, Saburi A, Sahebkar A. Curcuminoid treatment for knee osteoarthritis: a randomized double-blind placebo-controlled trial. Phytother Res. 2014; doi:10.1002/ptr.5174

51. Ozgoli G, Goli M, Moattar F. Comparison of effects of ginger, mefenamic acid, and ibuprofen on pain in women with primary dysmenorrhea. J Alt Comp Med. 2009:15:129-32.

52. Rahnama P, Montazeri A, Huseini HF, Kianbakht S, Naseri M. Effect of Zingiber officinale R. rhizomes (ginger) on pain relief in primary dysmenorrhea: a placebo randomized trial. BMC Comp Alt Med. 2012;12:92

53. Drobnic F, Riera J, Appendino G, Togni S, Franceschi F, Valle X, et al. Reduction of delayed onset muscle soreness by a novel curcumin delivery 
system (Meriva ${ }^{\circledR}$ : a randomised, placebo-controlled trial. J Int Soc Sports Nutr. 2014;11:31.

54. Agarwal KA, Tripathi CD, Agarwal BB, Saluja S. Efficacy of turmeric (curcumin) in pain and postoperative fatigue after laparoscopic cholecystectomy: a double-blind, randomized placebo-controlled study. Surg Endosc. 2011;25:3805-10.

55. Bundy R, Walker AF, Middleton RW, Booth J. Turmeric extract may improve irritable bowel syndrome symptomology in otherwise healthy adults: a pilot study. J Alt Comp Med. 2004;10:1015-8.

56. Brinkhaus B, Hentschel C, Von Keudell C, Schindler G, Lindner M, Stutzer H, et al. Herbal medicine with Curcuma and fumitory in the treatment of irritable bowel syndrome: a randomized, placebo-controlled, double-blind clinical trial. Scand J Gastroenterol. 2005;40:936-43.

57. Ryan JL, Heckler CE, Ling M, Katz A, Williams JP, Pentland AP, et al. Curcumin for radiation dermatitis: a randomized, double-blind, placebo-controlled clinical trial of thirty breast cancer patients. Radiat Res. 2013;180:34-43.

58. Srikanth VK, Fryer JL, Zhai G, Winzenberg TM, Hosmer D, Jones G. A meta-analysis of sex differences prevalence, incidence and severity of osteoarthritis. Osteoarthr Cartil. 2005;13:769-81.

59. Payne S. Sex, gender, and irritable bowel syndrome: making the connections. Gend Med. 2004;1:18-28.

60. Novacek G. Gender and gallstone disease. Wien Med Wochenschr 2006;156:527-33.

61. DerSimonian R, Laird N. Meta-analysis in clinical trials. Contr Clin Trials. 1986;7:177-88

62. Sahebkar A. A systematic review and meta-analysis of randomized controlled trials investigating the effects of curcumin on blood lipid levels. Clin Nutr. 2014;33:406-14.

63. Lee J, Oh H. Ginger as an antiemetic modality for chemotherapy-induced nausea and vomiting: a systematic review and meta-analysis. Oncol Nurs Forum. 2013;40:163-70.

64. Viljoen E, Visser J, Koen N, Musekiwa A. A systematic review and meta-analysis of the effect and safety of ginger in the treatment of pregnancy-associated nausea and vomiting. Nutr J. 2014;13:20.

65. Chaiyakunapruk N, Kitikannakorn N, Nathisuwan S, Leeprakobboon K, Leelasettagool $\mathrm{C}$. The efficacy of ginger for the prevention of postoperative nausea and vomiting: a meta-analysis. Am J Obstet Gynecol. 2006;194:95-9.

66. Kanerva L, Estlander T, Jolanki R. Occupational allergic contact dermatitis from spices. Contact Dermatitis. 1996;35:157-62.

67. Kandarkar SV, Sawant SS, Ingle AD, Deshpande SS, Maru GB. Subchronic oral hepatotoxicity of turmeric in mice - histopathological and ultrastructural studies. Indian J Exp Biol. 1998:36:675-9.

68. Kim DC, Ku SK, Bae JS. Anticoagulant activities of curcumin and its derivative. BMB Rep. 2012;45:221-6.

69. Singh D, Gupta R, Saraf SA. Herbs - are they safe enough? An overview. Crit Rev Food Sci Nutr. 2012:52:876-98.

70. Spolarich $A E$, Andrews L. An examination of the bleeding complications associated with herbal supplements, antiplatelet and anticoagulant medications. J Dent Hyg. 2007;81:67.

71. Tang M, Larson-Meyer DE, Liebman M. Effect of cinnamon and turmeric on urinary oxalate secretion, plasma lipids, and plasma glucose in healthy subjects. Am J Clin Nutr. 2008:87:1262-7.

72. Balaji S, Chempakam B. Toxicity prediction of compounds from turmeric (Curcuma longa L.). Chem Toxicol. 2010;48:2951-9.

73. Abebe W. Herbal medication: potential for adverse interactions with analgesic drugs. J Clin Pharm Ther. 2002;27:391-401.

74. Hodges PJ, Kam PC. The peri-operative implications of herbal medicines. Anaesthesia. 2002;57:889-99.

\section{Submit your next manuscript to BioMed Central and take full advantage of:}

- Convenient online submission

- Thorough peer review

- No space constraints or color figure charges

- Immediate publication on acceptance

- Inclusion in PubMed, CAS, Scopus and Google Scholar

- Research which is freely available for redistribution 